\title{
Is Executive Risk-Taking a Bridge Between Compensation Incentive and Innovation Intensity?
}

\author{
Sun Xiaolin ${ }^{1}$, Wang Sixue, *
}

\author{
${ }^{1}$ Dalian Polytechnic University \\ ${ }^{2}$ Dalian Polytechnic University \\ *Corresponding author. Email: 2058390669@qq.com
}

\begin{abstract}
Scholars at home and abroad pay attention to the influence of executive incentive on Enterprise R \& D innovation, most of them discuss the relationship between the two, ignoring the path of action. This paper studies the relationship between executive compensation incentive and enterprise innovation intensity, establishes the path of "compensation incentive - risk-taking level-innovation intensity" from the perspective of executive risk-taking, and tests the moderating effect of ownership concentration on the relationship between them. The results show that compensation incentive promotes the innovation intensity of enterprises; the risk-taking level of executives has a mediating effect in the relationship between the two; ownership concentration negatively regulates the relationship between compensation incentive and innovation intensity. The results are helpful for enterprises to formulate reasonable incentive mechanism and improve the efficiency of corporate governance.
\end{abstract}

Keywords: compensation incentive, innovation intensity, risk-taking level, ownership concentration

\section{INTRODUCTION}

With economic development entering the new normal, innovation is not only the primary driving force to promote economic growth, but also an important source of sustainable development of enterprises. General secretary Xi Jinping has repeatedly stressed the implementation of the innovation driven development strategy in the nineteen major reports, pointing out that innovation is the key to development. The modernization of the economic system cannot do without innovation, and we should speed up building our country into a new country. As the main body of national innovation, the innovation intensity of enterprises is an important support to improve the level of national innovation. Because of the characteristics of high investment, long R \& D cycle and uncertain future results, innovation activities have high risks. When executives make decisions, it is difficult to bring shortterm benefits in the face of a large amount of $R \& D$ funds output. In order to maximize their own benefits, they have risk aversion psychology in the decisionmaking of innovation projects, and will choose projects with relatively small risks and short-term benefits, and give up high-risk projects Risk and NPV are positive projects. Therefore, it is necessary to formulate a reasonable salary incentive system to stimulate executives to tend to high-risk projects in behavior decision-making, reduce the risk aversion psychology of executives, improve the innovation intensity of enterprises.

This paper, from the perspective of executive compensation incentive, discusses whether the implementation of compensation incentive can promote the improvement of innovation intensity, and explores its path of action, tests whether compensation incentive affects the innovation intensity by improving the level of executive risk-taking, and tests whether there are other factors that affect the relationship between the two.

\section{THEORETICAL ANALYSIS AND RESEARCH HYPOTHESIS}

\subsection{Executive compensation incentive and innovation intensity}

Foreign scholars such as Clies, Daniel $(2006)^{[1]}$ and Liang $(2011)^{[2]}$ believe that compensation incentive can effectively alleviate the conflict of interest between executives and shareholders caused by agency problems, slow down the risk aversion behavior of 
executives, increase the investment in risk projects, and improve the level of enterprise innovation. Xu yu, Feng Junke $(2017)^{[3]}$, Sun Zhiyi and others $(2019)^{[4]}$ found that compensation incentive is conducive to the development of $\mathrm{R} \& \mathrm{D}$ activities, while improving enterprise performance.

Innovation is the driving force for the sustainable development of enterprises. Technology and product upgrading can form the core competitiveness and improve the market position of enterprises while realizing the differentiation strategy of enterprises. However, the characteristics of large innovation risk, long innovation cycle and uncertain future earnings lead to executives' aversion to innovation. As the managers of daily activities, executives receive more information than shareholders, which leads to many agency problems. Sometimes, in order to ensure their own benefits, executives produce opportunistic behavior and choose projects with low risk and short-term profits, which ultimately damage the long-term interests and value of the enterprise. Therefore, reasonable compensation incentives for executives can help to curb opportunistic behavior of executives, encourage executives to increase $\mathrm{R} \& \mathrm{D}$ investment and improve enterprise innovation intensity.

Reasonable salary incentive can alleviate the conflict of interest between executives and shareholders, reduce agency costs, restrain executives' self-interest behavior, encourage executives to work hard, constantly innovate, and actively enhance enterprise value. Compared with other incentive methods, more stable salary incentive has more practical significance. It replaces the psychological crisis caused by R \& D failure in the spiritual level, increases the willingness of innovation investment, and improves the innovation intensity of enterprises. At the same time, compensation incentive is also related to the effect of corporate governance. Executives actively innovate in order to seek better governance effect, pursue innovation output efficiency, and further enhance the enterprise innovation intensity. Therefore, this paper puts forward a hypothesis:

$\mathrm{H} 1$ : there is a positive correlation between salary incentive and innovation intensity.

\subsection{Executive compensation incentive and risk- taking level}

In recent years, the policy of executive compensation assessment has been constantly improved. The compensation level of executives is not only linked to the current performance, but also related to the future business performance of the enterprise. The $\mathrm{R} \& \mathrm{D}$ innovation activities of executives taking risks just need a few years to see the results, which to some extent stimulates the improvement of executives' risk-taking level. Coles (2006) ${ }^{[5]}$ and Hagendor $(2011)^{[6]}$ take the data of the United States as an example, and find that higher salary can encourage executives to choose highrisk innovation projects, improve the risk-taking level of executives, and promote the effective development activities. Jin Jing (2019) ${ }^{[7]}$ studied the relationship between pay gap and risk-taking. The larger the pay gap, the higher the risk-taking level.

The demand level theory of incentive theory emphasizes that compensation incentive increases executive compensation, which leads to the realization of executives' low-level needs, the pursuit of high-level needs, the improvement of self-worth, more active efforts in daily management, the improvement of risk preference. Higher compensation incentives help executives invest more of their own funds in external companies, reduce the degree of risk aversion in the company, and improve the level of risk-taking of executives. Therefore, this paper puts forward the hypothesis:

$\mathrm{H} 2$ : salary incentive promotes the level of risktaking of executives.

\subsection{Mediating effect of risk-taking level}

Enterprises face countless risks in the process of production and operation, among which the risk coefficient of $\mathrm{R} \& \mathrm{D}$ and innovation activities is the largest, and the success or failure of R \& D activities affects the long-term development of enterprises. Simon $(2003)^{[8]}$, Brettel $(2011)^{[9]}$ think that the level of risktaking of executives has a promoting effect on innovation performance; Yang Siyu (2018) ${ }^{[10]}$ thinks that risk-taking has a positive impact on innovation investment of enterprises, and after adding information transparency, the level of risk-taking plays a mediating role in the relationship between them. It is particularly important to develop a reasonable incentive system to stimulate executives to pay attention to the development of $\mathrm{R} \& \mathrm{D}$ activities and improve the innovation intensity of enterprises.

Compared with other incentive methods, short-term compensation incentive brings obvious benefits to executives, promotes executives to take risks actively, increases $\mathrm{R} \& \mathrm{D}$ and enhances innovation intensity; meanwhile, compensation related to future performance promotes executives to continue R \& D and innovation, improves managers' risk-taking level and increases investment capital and increase innovation intensity. After the above analysis, this paper believes that the level of risk-taking of executives is a bridge between compensation incentive and innovation intensity, which plays a mediating role in the relationship between them. That is to say, the implementation of compensation incentive for executives promotes the improvement of enterprise innovation intensity by improving the level of 
risk-taking of executives. Based on the above

$\mathrm{H} 3$ : the level of risk-taking plays a mediating role in the impact of executive compensation incentive and enterprise innovation intensity.

\subsection{The moderating effect of ownership concentration}

Compensation incentive urges executives to actively take risks in $\mathrm{R} \& \mathrm{D}$ activities, enhance the innovation intensity of enterprises, and pursue better corporate governance effect. Ownership concentration happens to be an important factor in corporate governance, which can affect the effect of salary incentive and innovation intensity to a certain extent.

Ownership concentration mainly affects the relationship between compensation incentive and innovation intensity through the actual controller and shareholder regulatory function. With the improvement of ownership concentration, in the face of high-risk projects, large shareholders hinder the development of innovation activities in order to avoid the damage of their own income. They are more willing to use power to seek private interests. At this time, compensation incentive is one of the ways for shareholders to unite with executives, which reduces the effect of compensation incentive. When the ownership is dispersed, the cost of shareholders' supervision is high and the motivation is low. At this time, the effect of compensation incentive to promote innovation intensity will be significant; the higher the ownership concentration, the higher the willingness of shareholders' voluntary supervision. At this time, executives are subject to invisible pressure from shareholders, and their decision-making behavior is limited in major events, so the compensation incentive scheme for executives cannot achieve the expected effect. According to the above analysis, this paper puts forward the hypothesis:

H4: equity concentration negatively regulates the relationship between executive compensation incentive and innovation intensity.

\section{RESEARCH DESIGN}

\subsection{Sample selection and data sources}

In this paper, Shenzhen and Shanghai A-share listed companies as the research object, select the data from 2010 to 2019 as the observation value, and the data are processed as follows: remove the samples of the financial industry, remove the samples with missing values of variables, a total of 17678 samples are obtained, in order to prevent the impact of extreme values, $1 \%$ and $99 \%$ tail reduction is carried out on all continuous variables in this paper. All the data in this discussion, this paper puts forward the hypothesis: paper are from CSMAR database, and the data analysis is completed by stata15.0.

\subsection{Variable definition}

\subsubsection{Main research variables}

Innovation intensity (RDI) as the explained variable, scholars' methods of measuring innovation intensity include the proportion of $\mathrm{R} \& \mathrm{D}$ investment in total assets, the proportion of $\mathrm{R} \& \mathrm{D}$ investment in market value and so on. This paper uses the variable measurement method of Zuo Jingjing (2020) to measure the innovation intensity by using the relative index, and chooses the proportion of $\mathrm{R} \& \mathrm{D}$ investment in operating revenue to measure the innovation intensity. Compensation incentive (MI) is an explanatory variable, we choose the natural logarithm of the top three executives' total salary. As a moderating variable, the ownership concentration ratio (top1) is selected to measure the proportion of the largest shareholder.

The level of risk-taking is the intermediary variable of this study. The three-year rolling earnings volatility is used to measure the level of risk-taking of executives. This paper selects the return on assets (ROA) of the enterprise, calculates the three-year rolling standard deviation after industry and annual adjustment, and obtains the risk-taking level of senior executives:

$$
\frac{\text { risk }_{i, t}=}{\sqrt{\frac{1}{T-1} \sum_{i=1}^{T}\left(\text { ROAadj }_{i, t}-\frac{1}{T} \sum_{i=1}^{T} \text { ROAadj }_{i, t}\right)^{2}}}
$$

Among them, ROAadj is the return on assets adjusted by industry and year, and $\mathrm{T}$ is the research period of three consecutive years.

\subsubsection{Control variable}

This paper selects enterprise Size, Lev, Growth, Cash and DEP as the control variables from the aspects of enterprise scale, financial status, growth ability and corporate governance. In addition, there are industry and year. The specific measurement methods of variables are shown in Table 1.

\subsection{Model building}

In order to verify the hypothesis of this paper, the following models are constructed: model (1) tests the relationship between executive compensation incentive and innovation intensity; model (2) tests whether compensation incentive can improve executive risktaking level; model (3) tests the mediating effect of risktaking by adding risk variable on the basis of (1); model (4) adds ownership concentration (top1) and 
compensation incentive (MI) to test the moderating effect of Hypothesis 4 .

Table 1. Definition and measurement of variables

\begin{tabular}{|c|c|c|c|}
\hline Variable type & Variable name & Symbol & computing method \\
\hline $\begin{array}{l}\text { Explained } \\
\text { variable }\end{array}$ & Innovation intensity & RDI & R \& D investment / operating income \\
\hline \multirow[t]{3}{*}{$\begin{array}{l}\text { Explanatory } \\
\text { variable }\end{array}$} & compensation incentive & MI & Natural logarithm of top three executives' total compensation \\
\hline & risk-taking level & risk & Three year rolling earnings volatility \\
\hline & ownership concentration & top1 & Shareholding ratio of the largest shareholder \\
\hline \multirow[t]{7}{*}{ control variable } & Enterprise scale & Size & Natural logarithm of total assets \\
\hline & Asset liability ratio & Lev & Total liabilities / total assets \\
\hline & Growth & Growth & $\begin{array}{c}\text { (operating revenue of this year - operating revenue of last year) / } \\
\text { operating revenue of last year }\end{array}$ \\
\hline & cash flow & Cash & Net cash flow from operating activities / total assets \\
\hline & $\begin{array}{l}\text { Proportion of independent } \\
\text { directors }\end{array}$ & Dep & Number of independent directors / total number of directors \\
\hline & industry & Ind & Setting virtual variables by industry \\
\hline & Year & Year & Setting virtual variables by Year \\
\hline
\end{tabular}

$$
\begin{aligned}
& \mathrm{RDI}=\beta_{0}+\beta_{1} M I+\beta_{2} \text { Size }+\beta_{3} \text { Lev }+\beta_{4} \text { Growth }+\beta_{5} \text { Cash }+\beta_{6} \text { Dep }+\sum \text { Ind }+\sum \text { Year }+\varepsilon \\
& \text { risk }=\beta_{0}+\beta_{1} M I+\beta_{2} \text { Size }+\beta_{3} \text { Lev }+\beta_{4} \text { Growth }+\beta_{5} \text { Cash }+\beta_{6} \text { Dep }+\sum \text { Ind }+\sum \text { Year }+\varepsilon \\
& \mathrm{RDI}=\beta_{0}+\beta_{1} \mathrm{MI}+\beta_{2} \text { risk }+\beta_{3} \text { Size }+\beta_{4} \text { Lev }+\beta_{5} \text { Growth }+\beta_{6} \text { Cash }+\beta_{7} \text { Dep }+\sum \text { Ind }+\sum \text { Year } \\
& +\varepsilon \quad(3) \\
& \mathrm{RDI}=\gamma_{0}+\gamma_{1} \mathrm{MI}+\gamma_{2} \text { top } 1+\gamma_{3} \mathrm{MI} * \operatorname{top} 1+\gamma_{4} \mathrm{Size}+\gamma_{5} \mathrm{Lev}+\gamma_{6} \text { Growth }+\gamma_{7} \text { Cash }+\gamma_{8} \text { Dep }+\sum \text { Ind } \\
& +\sum Y e a r+\varepsilon
\end{aligned}
$$

\section{EMPIRICAL ANALYSIS}

\subsection{Descriptive statistics}

Table 2 The maximum value of compensation incentive is 16.653 , and the minimum value is 12.095 , which indicates that there are differences in the incentive degree of executives among different companies; the minimum value of innovation intensity is 0 , which indicates that some enterprises do not carry out innovation activities in some years, and the gap between the average value and the maximum value is large, which indicates that most enterprises have low innovation intensity and low risk-taking level The average value of risk-taking is 0.036 , which indicates that the level of risk-taking of senior executives is low, and the minimum value is only 0.001 , which indicates that the attitude of senior executives to risk is still evasive and unwilling to take more risks; the minimum shareholding ratio of the largest shareholder is 8.72 , the maximum is 74.09 , and the average value is 34.423 , which indicates that most enterprises in the sample have the phenomenon of equity concentration. Among the control variables, the standard deviation of enterprise size is 1.249 , which indicates that there are differences between enterprise sizes; the maximum and minimum of asset liability ratio indicate that enterprises have different degrees of using financial leverage; the minimum of growth and cash flow is negative, which indicates that individual enterprises are not doing well in operation, and the average value of the proportion of independent directors is close to the minimum, which indicates that most enterprises have different degrees of 
using financial leverage They are in the market average state.

Table 2. Descriptive Statistics

\begin{tabular}{l|l|l|l|l|l}
\hline Variable & Obs & Mean & Std.Dev. & Min & Max \\
\hline MI & 17678 & 14.328 & 0.665 & 12.095 & 16.653 \\
\hline RDI & 17678 & 4.614 & 4.97 & 0 & 43.015 \\
\hline risk & 17678 & 0.036 & 0.042 & 0.001 & 0.302 \\
\hline Size & 17678 & 22.075 & 1.249 & 19.726 & 26.574 \\
\hline Lev & 17678 & 0.406 & 0.203 & 0.028 & 0.967 \\
\hline Growth & 17678 & 0.183 & 0.4 & -0.561 & 4.028 \\
\hline Cash & 17678 & 0.058 & 0.097 & -0.343 & 0.68 \\
\hline Dep & 17678 & 0.375 & 0.054 & 0.308 & 0.6 \\
\hline top1 & 17678 & 34.423 & 14.196 & 8.72 & 74.09 \\
\hline
\end{tabular}

Table 3. Correlation Analysis

\begin{tabular}{l|l|l|l|l|l|l|l|l|l} 
& RDI & MI & risk & Size & Lev & Growth & Cash & Dep & top1 \\
\hline RDI & 1.000 & & & & & & & & \\
\hline MI & $0.057^{* * *}$ & 1.000 & & & & & & & \\
\hline risk & $0.043^{* * *}$ & $-0.053^{* * *}$ & 1.000 & & & & & & \\
\hline Size & $-0.231^{* * *}$ & $0.426^{* * *}$ & $-0.093^{* * *}$ & 1.000 & & & & & \\
\hline Lev & $-0.272^{* * *}$ & $0.089^{* * *}$ & $0.036^{* * *}$ & $0.522^{* * *}$ & 1.000 & & & & \\
\hline Growth & $0.050^{* * *}$ & $0.044^{* * *}$ & $-0.015^{* *}$ & $0.028^{* * *}$ & -0.001 & 1.000 & & & \\
\hline Cash & $0.034^{* * *}$ & $0.175^{* * *}$ & $-0.022^{* * *}$ & $0.056^{* * *}$ & $-0.150^{* * *}$ & $0.066^{* * *}$ & 1.000 & & \\
\hline Dep & $0.048^{* * *}$ & 0.001 & 0.003 & 0.008 & -0.002 & -0.006 & -0.003 & 1.000 & \\
\hline top1 & $-0.156^{* * *}$ & $0.015^{* *}$ & $-0.053^{* * * *}$ & $0.197^{* * *}$ & $0.060^{* * *}$ & $-0.025^{* * *}$ & $0.080^{* * *}$ & $0.062^{* * *}$ & 1.000 \\
\hline
\end{tabular}

\subsection{Correlation analysis}

According to the variable correlation table, the correlation coefficient between compensation incentive and innovation intensity is 0.057 , and it is significant at the level of $1 \%$, which preliminarily verifies the hypothesis 1 of this paper. The mediating effect of risktaking level needs to be further tested. Cash flow and growth are positively correlated with innovation intensity, while ownership concentration is negatively correlated with innovation intensity, indicating that the higher the ownership concentration is, the less conducive to enterprise innovation. At the same time, the VIF test of multicollinearity was carried out on the variables, and it was found that the mean value of VIF was 1.23 , indicating that there was no multicollinearity among the variables.

\subsection{Regression analysis}

Table 4 is the comprehensive results of multiple regression of variables in this paper. Model (1) tests the relationship between executive compensation incentive and innovation intensity. The regression coefficient of MI is 1.208 , which is significant at the level of $0.1 \%$. The two are positively correlated, indicating that executive compensation incentive can promote the improvement of enterprise innovation intensity. Hypothesis 1 is verified. In the control variables, the better the growth of enterprises and the higher the dep will have a positive impact on the innovation intensity of enterprises; the size and the LEV are negatively correlated with the innovation intensity, indicating that the debt pressure will reduce the $\mathrm{R} \& \mathrm{D}$ of enterprises of different sizes, and then the innovation intensity will be suppressed; the cash flow is negatively correlated with the innovation intensity However, it is not significant. This may be because many of the cash flows are used 
for the daily operation and management of the enterprise, and the funds used for R \& D and innovation are other sources.

Model (2) tests whether compensation incentive can improve the risk-taking level of executives. Regression shows that compensation incentive has a positive impact on the risk-taking level of executives, with a coefficient of 0.00175 and a significance of $5 \%$. It shows that the implementation of compensation incentive can change the attitude of executives towards risk and improve the risk-taking level of executives in the business process. Hypothesis 2 holds. The more significant control variables are size and LEV. The larger the enterprise scale is, the more problems the company faces, and the more cautious the executives are in decision-making, which reduces their risk-taking level. Lev is positively correlated with risk-taking, and the higher the debt is, the greater the risk executives have to bear. Combined with the test results of models (1) and (2), model (3) is the test of the mediating effect of risk-taking level. In model (3), the regression coefficients of MI and risk are both positive, and significant at the level of $0.1 \%$. According to the test principle of stepwise regression of mediating effect, the results show that the level of risktaking has mediating effect in the relationship between compensation incentive and innovation intensity, and it is partially mediating. Hypothesis 3 is verified. The regression coefficient of $\mathrm{MI}$ in model (3) is smaller than that in model (1), which also proves the mediating role of risk-taking level.

Table 4. multiple regression results

\begin{tabular}{|c|c|c|c|c|}
\hline & Model（1） RDI & Model (2) risk & Model（3） RDI & Model（4） RDI \\
\hline MI & $1.208 * * *(20.12)$ & $0.00175^{*}(0.32)$ & $1.207 * * *(20.12)$ & $1.643 * * *(11.88)$ \\
\hline risk & & & $4.589 * * *(5.48)$ & \\
\hline top1 & & & & $0.181 * * *(3.45)$ \\
\hline MI*top1 & & & & $-0.0153 * * *(-4.21)$ \\
\hline Size & $-0.828 * * *(-22.30)$ & $-0.00531 * * *(-15.93)$ & $-0.804 * * *(-21.51)$ & $-0.703 * * *(-18.64)$ \\
\hline Lev & $-4.381 * * *(-20.84)$ & $0.0247 * * *(13.10)$ & $-4.495 * * *(-21.30)$ & $-4.533 * * *(-21.69)$ \\
\hline Growth & $0.620 * * *(7.01)$ & $-0.00118(-1.49)$ & $0.625 * * *(7.07)$ & $0.573 * * *(6.52)$ \\
\hline Cash & $-0.639(-1.70)$ & $0.00197(0.58)$ & $-0.648(-1.72)$ & $-0.167(-0.45)$ \\
\hline Dep & $4.593 * * *(7.00)$ & $0.00388(0.66)$ & $4.575 * * *(6.98)$ & $5.279 * * *(8.09)$ \\
\hline Ind & control & control & control & control \\
\hline Year & control & control & control & control \\
\hline _cons & $\begin{array}{l}5.562 * * * \\
(6.18)\end{array}$ & $\begin{array}{l}0.139 * * * \\
(17.24)\end{array}$ & $\begin{array}{l}4.922 * * * \\
(5.43)\end{array}$ & $\begin{array}{l}-2.300 \\
(-1.14)\end{array}$ \\
\hline $\mathrm{N}$ & 17678 & 17678 & 17678 & 17678 \\
\hline R-sq & 0.111 & 0.019 & 0.112 & 0.124 \\
\hline adj. R-sq & 0.110 & 0.018 & 0.112 & 0.123 \\
\hline
\end{tabular}

$*$ p $<0.05, * * \mathrm{p}<0.01, * * * \mathrm{p}<0.001$, The value of $\mathrm{t}$ is in brackets.

Model (4) tests whether equity concentration has moderating effect on the relationship between compensation incentive and innovation intensity. The regression coefficient of MI * top1 is -0.0153 , And $0.1 \%$ level is significant, which indicates that ownership concentration negatively regulates the relationship between compensation incentive and innovation intensity. The reason is that with the increase of ownership concentration, shareholders are resistant to high-risk innovation projects, ensuring their own interests and hindering R \& D innovation. The second reason is that shareholders' supervision is improved, executives' decision-making is limited, and risk-taking projects similar to innovation are reduced Hypothesis 4 is verified.

\subsection{Robustness check}

In order to verify the reliability of the results of this paper, change the measurement method of innovation intensity of the main research variables in this paper, use the proportion of $\mathrm{R} \& \mathrm{D}$ investment in total assets to 
measure, and use stata15.0 to carry out a calculation. The test results are shown in Table 5. The regression results are not very different from the research results of this paper, and the research hypothesis is still valid, which verifies the robustness of the results of this paper.

Table 5. Correlation Analysis

\begin{tabular}{l|l|l|l|l} 
& Model (1) & Model (2) & Model (3) & Model (4) \\
\hline MI & $0.862 * * *(23.19)$ & $0.00175^{*}(0.32)$ & $0.863 * * *(23.20)$ & $1.191 * * *(13.84)$ \\
\hline risk & & & $1.618 * *(3.12)$ & \\
\hline top1 & & & & $0.138^{* * *(4.22)}$ \\
\hline MI*top1 & & & & $-0.0102 * *(-4.52)$ \\
\hline CV & Yes & Yes & Yes & Yes \\
\hline $\mathrm{N}$ & 17678 & 17678 & 17678 & 17678 \\
\hline adj. R-sq & 0.133 & 0.018 & 0.133 & 0.135 \\
\hline
\end{tabular}

$* \mathrm{p}<0.05, * * \mathrm{p}<0.01, * * * \mathrm{p}<0.001$, The value of $\mathrm{t}$ is in brackets.

\section{CONCLUSION}

Based on the data of a shares in Shenzhen and Shanghai from 2010 to 2019, this paper discusses the relationship between executive compensation incentive and enterprise innovation intensity, and analyzes the path and influencing factors. The following conclusions are drawn: compensation incentive promotes the improvement of enterprise innovation intensity; risktaking level has a mediating effect in the influence of compensation incentive and innovation intensity, and compensation incentive can promote innovation Intensity is because it improves the risk-taking level of executives to a certain extent; ownership concentration, as a moderating variable, significantly negatively moderates the relationship between compensation incentive and innovation intensity.

Combined with the conclusion of this paper, the following suggestions are given: first, set up a reasonable incentive mode for senior executives, and carry out diversified incentive. In addition to the current more ways of salary incentive and equity incentive, it can also provide spiritual incentives for executives, such as setting up a reasonable promotion mechanism to encourage executives to actively operate the enterprise to achieve the actual incentive effect, encourage executives to take risks, and enhance the innovation intensity. In recent years, the innovation intensity of enterprises has been improved, but the final transformation results are not high, and executives should be inspired to pay attention to the quality of R \& $\mathrm{D}$ innovation. Second, pay attention to incentive monitoring and strengthen risk management. In order to avoid excessive risk investment for executives seeking high returns, we should strengthen the risk management within the scope of incentives and effectively supervise the behavior of executives. Third, improve the corporate governance mechanism and optimize the ownership structure. It is necessary to strengthen the degree of restriction on the ownership concentration of enterprises, prevent the excessive ownership concentration from affecting the development and implementation of enterprise innovation activities, and prevent the large shareholders from using their power to damage the interests of others; it is necessary to reasonably allocate and adjust the proportion of the largest shareholder to control within an effective and reasonable range by using the relationship of mutual supervision among shareholders.

\section{REFERENCES}

[1] Clies J, Daniel N, Naveen L. Managerial Incentives and Risk-taking $[\mathrm{J}]$. Journal of Financial Ecinomics, 2006,79(2):431-468.

[2] LIANG J W. R\&D Horizon and CEO Compensation [J]. Accounting Review, 2011(53).

[3] $\mathrm{Xu} \mathrm{Yu,} \mathrm{Feng} \mathrm{Junke.} \mathrm{Internal} \mathrm{control,} \mathrm{executive}$ incentive and innovation performance: An Empirical Study Based on the effectiveness of internal control [J]. Soft science, 2017,3:79-82.

[4] Sun Zhiyi, Wang Yuxia. The influence of leadership structure and CEO incentive on Enterprise Innovation -- Based on the empirical data of Listed Companies in strategic emerging industries [J]. Economic issues, 2019(01):60-67.

[5] Coles J. L., Daniel N. D., Naveen L. Managerial Incentives and Risk-taking [J]. Journal of Financial Economics, 2006(2):431-468.

[6] Hagendor J., Vallascas, F. CEO Pay Incentives and Risk-taking: Evidence from Bank Acquisitions [J]. Journal of Corporate Finance, 2011(4): 1078-1095. 
[7] Jin Jing, Sun Ming. Marketization process, external equity of executive compensation and enterprise risk-taking $[\mathrm{J}]$. Jilin Journal of industry and commerce, 2019(01):11-17.

[8] Simon M, Houghton S.M. The Relationship between Over-confidence and the Introduction of Risky Products: Evidence from a Field Study [J]. Academy of Management Journal,2003,46(2):139149.

[9] Brettel M, Eleven N.J. Innovation Culture, Collaboration with External Partners and NPD Performance $[\mathrm{J}]$. Creativity and Innovation Managements,2011,20(4):253-272.

[10] Yang Siyu. Enterprise innovation investment, risk taking and accounting information transparency [J]. Research on higher financial education, 2018(04):79-84. 